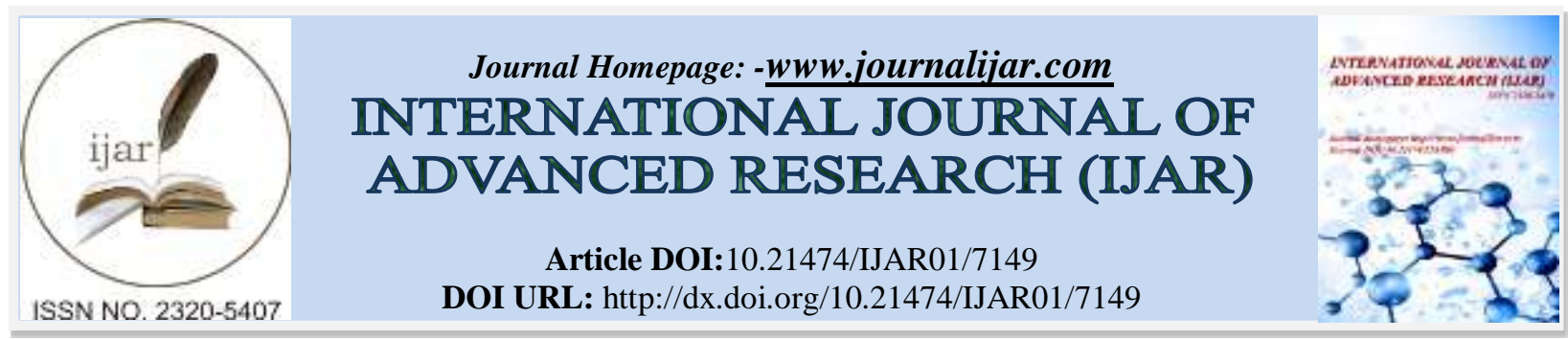

RESEARCH ARTICLE

\title{
METACOGNITION SKILLS STUDENTS ON THE SYNECTIC LEARNING MODEL AT SCHOOL OF JEMBER COFFEE PLANTATION AREA, INDONESIA.
}

Nurul Komaria, Suratno, Yushardi, I Ketut Mahardika. University of Jember, Jember, Indonesia 68121.

\section{Manuscript Info \\ Manuscript History \\ Received: 20 March 2018 \\ Final Accepted: 22 April 2018 \\ Published: May 2018}

Keywords:-

Metacognition, Synectic, Coffee

Plantation Area.

\section{Abstract}

Metacognition skills are an important part of teaching and learning, especially in the coffee plantation area of Jember, Indonesia. Metacognition skills need to be developed in students to become selfregulated learner. The purpose of this study is to examine the effect of the synectic model on the students' metacognition skills in the school of coffee plantation area. This research is a comparative research with descriptive method. Metacognition skills were measured using the Metacognitive Awareness Inventory (MAI) questionnaire provided before and after the study. Data were analyzed using SPSS 23 for Windows program. The result of this research is variation of metacognition ability with rating scale consist of super, ok, development, can not really, and not yet.

Copy Right, IJAR, 2018,. All rights reserved.

\section{Introduction:-}

Education is a very important role in creating intelligent, peaceful and open mind human. Therefore, renewal in the field of education should be undertaken to improve the quality and quality of education. Increasing the quality and quality of education one of them is done by improving the process of teaching and learning activities. Teachercentered teaching-learning activities as well as emphasizing the mastery of cognitive concepts with objective tests make passive learners in learning because they tend to learn to remember / memorize without understanding what their teacher taught, but it also seems monotonous because the pattern of teaching is the same, so they have difficulty in learning. As a result when students are faced with problems, students have difficulty to solve them. So that's way, teachers are required to develop new nuances in teaching and learning process to improve the quality of learning one by empowering metacognition skills (Siegel 2012).

Empowerment of metacognition skills today is not much done. This happens because of the lack of knowledge of teachers who are unaware that metacognition skills can affect student learning. If this continues to happen it will make it difficult for students at higher levels of education in solving learning problems (Suratno 2011). Learners will solve problems properly if use the capacity of thinking well. But unfortunately the practice of learning its use is far from optimal. This can be reflected in the difficulties that arise in a lesson, such as the difficulty of choosing a learning strategy, focusing or remembering that leads to low learning outcomes.

To reduce the low learning outcomes, it is necessary to optimize the ability to think systematically. Starting from the planning stage, choosing the right strategy for solving a problem, monitoring, correcting and analyzing learning progress and doing reflection if needed. So that when a person has been able to control the way of thinking about his 
thinking by monitoring and judging for himself on something learned his metacognitive skills have been used optimally (Schraw and Dennison 1994). With the metacognition, students are expected to solve the problem of learning to understand the success that has been achieved.

Achievement of learning outcomes can be seen from academic performance. Learners with good metacognition exhibit good academic performance compared to students with low metacognitive awareness (Coutinho, 2007). According to Mango (2010) in Jayapraba, G (2013), teachers should raise the awareness of metacognition of learners to improve their learning ability. So that more learners know about effective learning strategies, their metacognitive skills will increase, followed by high-class performance (Henter 2014). This happens because the metacognition of each individual can regulate their cognitive activity (Livingstone 2003). The development of metacognition skills is a valuable educational goal, because this skill can help them become independent learners who are responsible for their own learning willingness (Eggen and Kauchak in Suratno. 2011).

Learning Science is ideally ideally centered (Student Centered Learning), this refers to the constructivism view that learners have the potential to develop their awareness. Therefore, teaching IPA is not enough if it is learned only by providing knowledge that is only informational, it would be better if the students are actively involved in finding themselves and associated with life around them so that learning becomes meaningful. Attempts to convey meaningful material to learners can be made by linking between the material taught to the real-world situations of the students so as to encourage students to make the knowledge connections he / she posts with their application in their lives. One step that can be done is to utilize the environment around the coffee plantation as a source of learning. People around the plantation, already familiar with coffee plants. With the coffee plants around the plantation, students can more actively seek the desired information. With so empowering student-centered learning can be done in the coffee plantation environment. As mentioned above, student-centered learning should ideally be done in order to help them become independent learners. To become independent learners, it is necessary to model synoptic learning that belongs to the family of personal models. That is, every educational process is strived to enable a person to understand himself well, able to assume responsibility for education and more creative to achieve a better quality of life. The synectic learning model is quite attractive in enhancing productive thinking, educational empathy, and interpersonal affinity making it applicable to students at all ages and all areas of the curriculum (Joyce, 2009: 271). Synectic learning model can also combine with other models easily so that its application is more effective and growing every time (Joyce, 2009: 271).

The synectic learning model that emphasizes analogies and linking learning materials with real-world contexts allows students to gain much experience in interpreting problems and generating different ideas in solving a problem (Joyce, 2009). This will help students to plan, monitor and evaluate the results (Schraw and Dennison 1994). So through the synectic learning model with contextual approach is expected to improve metacognition skills. Based on this, the authors conducted a study on "Student Metacognition Skills on the Synectic Learning Model at School Jember Coffee Plantation Area, Indonesia. The purpose of this research is to know whether the cinectic model proved to be reliable in improving metacognition skills in junior high school students in Coffee Plantation.

\section{Research Method:-}

This research is a comparative study. Comparative research is a study conducted to compare the value of one variable with other variables, this study more than one sample. This research was conducted on grade VII students at a public school near coffee plantation in Jember regency, Indonesia. The choice of the seventh grader because believes that at the age above 12 years old, students are able to solve special problems and can think logically. The research instrument was a MAI questionnaire developed by Scraw, G. \& Dennison, R.S consisting of 52 questions. MAI Questionnaires are given at the beginning and at the end of the lesson, the student is required to provide a check mark $(\sqrt{ })$ on the provided column. The study was conducted in March 2018, with respondents totaling 57 students.

MAI can be used to measure knowledge of metacognitive cognition and regulation (metacognitive awareness). Metacognitive knowledge consists of three measurement scales: eight items of declarative knowledge, four procedural knowledge items, and five conditional knowledge items. The metacognitive regulation consists of five measurement scales, seven item planning, ten item management strategy, seven comprehensive monitoring items, five debugging strategy items, and six item evaluation. Each item has an answer option. 
The results of the questionnaire were corrected with incorrect scores 0 and correct 1 . The scores obtained were converted to a scale of 0 -100. The categorization of metacognition skill level with ratting scale from Green (2002) consists of super $(85 \leq \mathrm{x}<100)$, ok $(68 \leq \mathrm{x}<85)$, development $(51 \leq \mathrm{x}<68)$, can not really $(34 \leq \mathrm{x}<51)$, risk $(17 \leq \mathrm{x}$ $<34)$, and not yet $(0 \leq x<17)$.

\section{Findings and Discussion:-}

The results of the mean measurements of metacognition skills of pretest and postes are listed in Table 1 .

Table 1:-Metacognitive Skills of Junior High School Students at Coffee Plantations

\begin{tabular}{|l|l|l|l|l|l|}
\hline No & Variabel & Pretes & Kategori & Postes & Kategori \\
\hline 1 & Declarative Knowledge & 55,1 & Development & 74,5 & Ok \\
\hline 2 & Prosedural Knowledge & 54,4 & Development & 74,6 & Ok \\
\hline 3 & Conditional Knowledge & 54 & Development & 72,6 & Ok \\
\hline 4 & Planning & 61,3 & Development & 87,7 & Ok \\
\hline 5 & $\begin{array}{l}\text { Information Management Strategies } \\
\text { (IMS) }\end{array}$ & 52,4 & Development & 70,7 & Ok \\
\hline 6 & Comprehension Monitoring $(C M)$ & 60,6 & Development & 80,7 & Ok \\
\hline 7 & Debugging Strategies $(D S)$ & 62,5 & Development & 83,5 & Ok \\
\hline 8 & Evaluation & 61,4 & Development & 85,6 & Ok \\
\hline
\end{tabular}

Table 1 shows that the average pretest score for metacognition skill indicator is Declarative Knowledge, Procedural Knowledge, Conditional Knowledge, Planning, Information Management Strategies, Comprehension Monitoring (CM), Debugging Strategies (DS) and Evaluation are in Development category, while the average postes score appears on all indicators in the Ok category. In all indicators of metacognition skills, namely Declarative Knowledge, Procedural Knowledge, Conditional Knowledge, Information Management Strategies (IMS), Comprehension Monitoring (CM), Debugging Strategies (DS) and Evaluation appears to increase the category of Development into. This is reflected in the average shift in pretest to postes as shown in Table 2.

Table 2:-Average shift in Metacognitive Skills of Junior High School Students at Coffee Plantations

\begin{tabular}{|l|l|l|l|}
\hline No & Variabel & Kenaikan & $\%$ Kenaikan \\
\hline 1 & Declarative Knowledge & 16,4 & $35,21 \%$ \\
\hline 2 & Prosedural Knowledge & 20,2 & $37,13 \%$ \\
\hline 3 & Conditional Knowledge & 18,6 & $34,44 \%$ \\
\hline 4 & Planning & 15,6 & $43,07 \%$ \\
\hline 5 & Information Management Strategies $(I M S)$ & 17 & $34,92 \%$ \\
\hline 6 & Comprehension Monitoring $(C M)$ & 17,53 & $33,17 \%$ \\
\hline 7 & Debugging Strategies $(D S)$ & 21,1 & $33,60 \%$ \\
\hline 8 & Evaluation & 17,3 & $39,41 \%$ \\
\hline
\end{tabular}

From Table 2 shows that there is a shift in the average score from pretest to postes ranged from $33.17 \%-43.07 \%$. The shift of $33.17 \%$ is on the Comprehension Monitoring indicator, while the shift of $43.07 \%$ is on the Planning indicator. For indicators of Declarative Knowledge, Procedural Knowledge, Conditional Knowledge, Information Management Strategies (IMS), Debugging Strategies (DS) and Evaluation are in that range.

Based on the average of the eight indicators of metacognition skills, it is known that the highest percentage is the metacognition skill of Planning indicator with a percentage of $43.07 \%$. Then Evaluation with percentage $39,41 \%$, then Procedural Knowledge with percentage 37,13\%, then Declarative Knowledge with percentage 35,21\%, Information Management Strategies with percentage 34,92\%, Conditional Knowledge with percentage 34,44\%, Debugging Strategies with a percentage of $33.60 \%$ and the lowest is Comprehension Monitoring with a percentage of $33.17 \%$. The manova test of the effect of the synthetic model on the metacognition skills of students in the school of coffee plantation area is shown in Table 3. 
Table 3:-Recapitulation of Manova Test Results Influence of the Synthetic Learning Model on Metacognition Skills

\begin{tabular}{|c|c|c|c|c|c|c|c|c|}
\hline \multicolumn{9}{|c|}{ Multivariate Tests ${ }^{\mathrm{a}}$} \\
\hline \multicolumn{2}{|l|}{ Effect } & Value & $\mathrm{F}$ & $\begin{array}{c}\text { Hypothesis } \\
\text { df }\end{array}$ & Error $\mathrm{df}$ & Sig. & $\begin{array}{l}\text { Noncent. } \\
\text { Parameter }\end{array}$ & $\begin{array}{l}\text { Observed } \\
\text { Power }^{\mathrm{c}}\end{array}$ \\
\hline \multirow[t]{4}{*}{ Intercept } & Pillai's Trace & ,979 & $608,984^{\mathrm{b}}$ & 8,000 & 105,000 &, 000 & 4871,871 & 1,000 \\
\hline & Wilks' Lambda &, 021 & $608,984^{b}$ & 8,000 & 105,000 &, 000 & 4871,871 & 1,000 \\
\hline & Hotelling's Trace & 46,399 & $608,984^{\mathrm{b}}$ & 8,000 & 105,000 &, 000 & 4871,871 & 1,000 \\
\hline & Roy's Largest Root & 46,399 & $608,984^{\mathrm{b}}$ & 8,000 & 105,000 &, 000 & 4871,871 & 1,000 \\
\hline \multirow[t]{4}{*}{ TEST } & Pillai's Trace &, 559 & $16,654^{b}$ & 8,000 & 105,000 &, 000 & 133,231 & 1,000 \\
\hline & Wilks' Lambda & 441 & $16,654^{b}$ & 8,000 & 105,000 &, 000 & 133,231 & 1,000 \\
\hline & Hotelling's Trace & 1,269 & $16,654^{b}$ & 8,000 & 105,000 &, 000 & 133,231 & 1,000 \\
\hline & Roy's Largest Root & 1,269 & $16,654^{\mathrm{b}}$ & 8,000 & 105,000 &, 000 & 133,231 & 1,000 \\
\hline
\end{tabular}

According to Table 3 , the results obtained have p-value $(s i g=0,000)$ for different multivariate tests. The fourth result shows $<0.05$ so that there is a significant influence of the dependent variable (in this study metacognition skills) on the independent variables (in this study the synoptic learning model).

\section{Discussion:-}

The study sample was grouped into six categories of groups, super group, ok group, development group, can not really group, and not yet group to find the difference of students' metacognition ability. Students are grouped based on average results of each indicator processed from questionnaire data by grouping six rankings. Based on data of pretest score score for metacognition skill indicator that is Declarative Knowledge, Procedural Knowledge, Conditional Knowledge, Planning, Information Management Strategies (IMS), Comprehension Monitoring (CM), Debugging Strategies (DS) and Evaluation goes into the range of $54 \leq \mathrm{x}<61.4$ is included in the Development category. The junior high school students in the coffee plantations belong to this category are the majority already knowledgeable about what information should be mastered to solve the problems and they already know the weaknesses and their strengths, it just needs to be encouraged and supported (Green 2002). The support can be motivated by the teacher. In this case, the teacher acts as a facilitator should develop the metacognition skills of the students since this ability does not appear alone without being facilitated. This is in line with the opinion of Cao and Nietfeld (2007) which states that metacognition does not appear by itself, but must be encouraged by the teacher. Therefore, in learning the teacher must empower the students metacognition skills can develop.

While based on the average data postest score for all indicators of metacognition skills entered into the range $70.7 \leq$ $\mathrm{x}<87.7$ included in the Ok category. Junior students with Ok metacognition categories are generally aware of their own thought processes so that they can differentiate the input stage - elaboration and output. Sometimes, in learning they also use models to organize their own thinking and learning. According to Schraw and Dennison (1994) students who are skilled at self-assessment are students who are aware of their abilities. This certainly helps students in developing learning strategies, learning styles, learning skills, and the utilization of the environment in a variety of forms as the development of self-managing habits. So it is not surprising that students with the Ok category can become independent learners who can self-regulate by planning, monitoring understanding and evaluation (Schraw \& Dennison, 1994).

Metacognition ability consists of knowledge of metacognition or knowledge of cognition and regulation of cognition or metacognition regulation (Dasoeta, 2008). Metacognition knowledge consists of Declarative Knowledge, Procedural Knowledge, and Conditional Knowledge. Metacognition regulation consists of Planning, Information Management Strategies (IMS), Comprehension Monitoring (CM), Debugging Strategies (DS) and Evaluation (Schraw \& Dennison, 1994). When compared to the average score of pretest and posttest score for metacognition skill indicator between knowledge ability of cognition and cognition regulation showed almost same result / not much different that is in category Ok. The proximity of the value obtained occurs because the ability of knowledge about cognition can not be separated from the regulation of cognition regulation considering the importance of cognition regulation as a metacognition knowledge strategy to achieve cognition goals (Dasoeta. 2008). If the ability of both is good, then the student can solve the problem well in learning. This is in accordance with the results of Siegel's research (2012), students who have knowledge of good cognition tend to have good cognitive regulation as well. So metacognition skills need to be developed through a process or form of learning that can train metacognitive knowledge and metacognitive regulation. The process for developing metacognition can be done by 
using strategies, approaches, learning models that require the existence of activities related to awareness and cognitive regulation.

As described above, every aspect of metacognition skills has a relationship from one to another (Flavell 1979). So if someone has good declarative knowledge, so procedural knowledge is also good. Declarative knowledge is related to procedural knowledge, where when one realizes that one does not understand something, it will have a strategy to find the information needed, that strategy is part of procedural knowledge (Flavell.1979). Similarly, the relationship of procedural knowledge with conditional knowledge, if one already has the necessary learning strategies, then he should understand also when and why the strategy is used (Scraw \& Dennison 1994). Conversely, when a student has been able to use a good learning strategy in a given situation, he has knowledge of how to use good learning strategies (Scraw \& Dennison 1994). When they know more about effective learning strategies, the metacognitive abilities will increase and the high-grade classroom achievement will follow. The metacognition skills possessed by each individual can regulate their cognitive activity (Livingstone 2003) As mentioned above, student-centered learning should ideally be done in order to help them become independent learners. To become independent learners, it is necessary to model synoptic learning that belongs to the family of personal models. That is, every educational process is strived to enable a person to understand himself well, able to assume responsibility for education and more creative to achieve a better quality of life.

As the results are written in the table, the sign value. 0,000 means that there is a significant influence of the synthetic learning model on metacognition skills. The success of synectic learning model that influences metacognition skills is inseparable from the syntax of learning model. The syntax of learning models that involves analogy activities can empower metacognition skills because students can remember concepts in new ways using their words, linking knowledge which has learned with everyday life and students can synthesize concepts in a better way so as to enhance students' Khan \& Mahmood 2017). This is in line with the opinion of Sierra-Jones (2011), that the usage of synectic learning model as an effective method to develop conceptual understanding which is one aspect of metacognition skills. The form of a reasonably attractive synectic learning model in enhancing productive thinking and empathy allows students to gain much experience in interpreting problems and generating different ideas in solving a problem. It will certainly help students to plan, monitor, and evaluate the results. Thus, through the synoptic learning model is expected to improve metacognition skills.

\section{Conclusion:-}

Students in coffee plantations have different metacognition skills. The result of research shows that there is influence of learning model to metacognition skill, based on pretest and posttest result there is a shift of category increase from development to ok on cognition knowledge ability and cognitive regulation before and after learning.

\section{Bibliography:-}

1. Nietfeld, J. L. 2007. College StudentMetacognitive Awareness of Difficulties in Learning the Class Content Does Not Automatically Lead to Adjusment of Study Strategies. Australian Journal of Educational \& Developmental Psychology. Vol (7) : 31-46

2. Coutinho, S. A. 2007. The relationship between goals, metacognition, and academic success. Educate Vol. 7, No.1, pp. 39-47.

3. Dasoeta, A. 2009. Introduction : Metacognition, more than the lognes monster. Internatinal Electronic Journal of Elementary Education Vol 2 (1)

4. Flavell, J.N. 1979. Metacognition and Cognitive Monitoring : A New Area of Cognitive Developmental Inquiry. American Psychologist, 34 (10), hlm 906-911

5. Green, R. 20Cao, L \& 02. Better Thinking Learning an Introduction to Cognitive Education. Western Cape Education Department

6. Henter, R. 2014. Developing Metacognitive skills as a foundation of learning a foreign language. Roumanian Journal of Experimental Applied Psychology, 5 (1)

7. Jayapraba, G. 2013. Metacognitive instruction and cooperative learning-strategies for promoting insightful learning in science. International Journal on New Trends in Education and Their Implications. Vol, 4 Issue 1, Article 15 ISSN 1309-6249

8. Joyce, B., Weil, M., \& Calhoun, E. 2009. Model of Teaching (Model Model Pengajaran Edisi Kedelapan). Yogyakarta : Pustaka pelajar 
9. Khan, A.A \& Mahmood, N. 2017. The Role of the Synectics Model in Enhancing Students Understanding Geometrical Concepts. Journal of Research and Reflections in Education. JRRE Vol 11 No 2, pp 253-264.

10. Livingston, J.A.2003. Metacognition :An Overview

11. Schraw \& Sperling-Denisson.1994. Assesing Metacognitive Awareness. Contemporary Educational Pshicology, 19, 460-475

12. Siegel, M.A. 2012. Filling in the Distance Between Us : Group Metacognition During Problem Solving in a secondary Education Course. J Science Education Technology. doi: 10.1007/s10956-011-9326-Z

13. Sierra- Jones, C (2011). Applied Synectics to Teach Community Development for Living and Learning Communities to Resident Advisors and Community Assistants at California State University Monterey Bay. Capstone and Theses, Paper 429

14. Suratno. 2011. Metacognitive Ability with Metacognitive Awareness Inventory (MAI) on High School Biology Learning with Jigsaw Strategy, Reciprocal Teaching (RT) and Jigsaw-RT joint. Journal of Education and Learning, Volume 18, Nomor 1, April 2011 